Volume 14 - Número 2 - ago/dez de 2019

\title{
NAS ONDAS DO MEME EM PROL DO MULTILETRAMENTO
}

\author{
ON THE WAVES OF MEME TOWARDS MULTILITERACY
}

\author{
Kátia Diolina ${ }^{1}$ \\ Luzia Bueno ${ }^{2}$
}

\begin{abstract}
RESUMO: Este trabalho tem o objetivo de discutir o multiletramento, conforme prescrito na Base Nacional Comum Curricular (BNCC), de maneira a problematizar, mas, sobretudo, a estudar as possibilidades de análise e de ensino de textos multissemióticos (os memes) que circulam na web. Trata-se de um estudo em prol da construção de um modelo didático do gênero meme, a fim de dar instrumentos para professores e elaboradores de materiais didáticos para que possam realizar um bom trabalho de ensino, uma vez que entre a BNCC enquanto prescrição e a realização das atividades há uma boa distância. Para tanto, recorremos aos referenciais do Interacionismo Sociodiscursivo (BRONCKART, 1999) em que atuam de forma decisiva na didática das línguas por meio do ensino dos gêneros textuais (DOLZ; SCHNEUWLY, 2004) e dos estudos de Wulf (2013), Lemke (2010); Santaella (2010); Rojo (2012; 2013); Rojo e Moura (2019) que se centram nos aspectos miméticos, multissemióticos da linguagem. Ressaltamos que com a multiplicidade de valores (LEMKE, 2010) e, em contrapartida, com o imediatismo na apreensão e construção dos sentidos (SANTAELLA, 2010), o processo de ensino e de aprendizagem das línguas exige, cada vez mais, uma pedagogia dos multiletramentos (Novo Grupo de Londres, 1996), já que, conforme Kleiman e Morais (1999, p.92), as novas tecnologias não vieram "usurpar" a linguagem, mas, sobretudo, multiplicá-la, como os memes. De autoria relativizada, o meme é um gênero que viraliza na rede, dialogando com diferentes temas e textos, (des)construindo múltiplos comportamentos, ideias e ideais, num embate de vozes verbais e não-verbais (estáticas ou não), o que o torna um profícuo recurso didático para o ensino mais crítico dos alunos e, ainda, permite a nós uma discussão sobre a importância das orientações, ainda que lacunares, da BNCC sobre o tema.
\end{abstract}

PALAVRAS-CHAVE: Multiletramentos. BNCC. Memes.

ABSTRACT: This paper aims to discuss multiliteracy, as prescribed in the Common National Curriculum Base (BNCC), to problematize and, especially, to study the possibilities of analyzing multisemiotic texts (the so-called "memes") that circulate on the web. This is a work to build a didactic model of the meme genre in order to provide tools for teachers and textbook makers to do a good job of teaching, as between the BNCC as a prescription and performing the activities a good distance away. For this, we use the references of Sociodiscursive Interactionism (BRONCKART, 1999) in which they act decisively in the didactics of languages through the teaching of textual genres (DOLZ; SCHNEUWLY, 2004), as well as the studies of Wulf (2013), Lemke (2010); Santaella (2010); Rojo (2012; 2013); Rojo e Moura (2019) that focus on the mimetic, multisemiotic aspects of language. We emphasize that with a multiplicity of values (LEMKE, 2010) and, on the other hand, with the immediacy in the apprehension and construction of the senses (SANTAELLA, 2010), the process of language teaching and learning increasingly demands a pedagogy of multiliteracy. (New London Group, 1996), since, according to Kleiman and Morais (1999, p.92), the new technologies did not "usurp" language but multiply it, as memes do. Having a relativized authorship, the meme is a genre that goes viral in web, dialoguing with different themes and texts, (de)constructing multiple behaviors, ideas and ideals, in a clash of verbal and nonverbal voices (static or not), which makes the meme an useful teaching resource for a teaching more critical and conscient and also allows us a discussion about the importance of the BNCC guidelines, still incomplete, on the subject.

KEYWORDS: Multiliteracies. BNCC. Memes.

\section{Introdução}

Vivemos o tempo da multiplicação de sentidos, de culturas, de recursos, de valores, de ritos e de representações. Uma sociedade que está em interação a todo momento, tendo a linguagem e suas transformações um papel de destaque, particularmente no que tange à

\footnotetext{
${ }^{1}$ Professora Doutora em Linguística Aplicada e Estudos da Linguagem - LAEL, com pós-doutorado no programa em Educação da Universidade São Francisco. E-mail: katiadio@gmail.com

2 Professora do programa de pós-graduação em Educação da Universidade São Francisco. E-mail: luzia.bueno@usf.edu.br
} 
Volume 14 - Número 2 - ago/dez de 2019

navegação da web. Santaella (2014) alerta que esse processo não ocorre somente quanto à configuração do registro (a língua enquanto código), mas sobretudo quanto à construção dos modos de interação por meio da linguagem. Em outros termos, dos gêneros textuais. Por meio da tela, o texto navega nas ondas da net, liberta-se da linearidade, reinventando a leitura, o diálogo, a interpretação, a intercompreensão, os efeitos de sentidos, sejam dos signos verbais sejam dos não-verbais que podem ser fixos ou animados, gráficos, mapas, além dos sons (músicas, falas) e dos links que podem nos transportar a novas possibilidades de leitura, de interação. Para a autora, os signos são os grandes responsáveis não só por moldar, mas também por propiciar os surgimentos de novos ambientes socioculturais, como o da internet.

Quanto ao contexto digital, Lima e De Grande (2013, p. 37) defendem que existe um novo ethos, uma nova maneira de se comportar a partir de uma "mentalidade 2.0", fazendo analogia a web 2.0. Essa mudança é possível porque houve uma alteração na própria internet que passou de 1.0, que se centrava mais no processamento e armazenamento de dados, para a 2.0 que impacta sobre as relações humanas de modo mais ativo, colaborativo, participativo, mais coletivo. Segundo Santaella (2010, p. 21), “[...] a internet é um cérebro digital global que, graças às plataformas de redes sociais, transmite publicamente relações, interesses, intenções, gostos, desejos e afetos dos usuários, em processos incessantes e velozes".

Essa condição requer novos letramentos, uma vez que as relações, os diálogos são elevados ao máximo e trazem implicações diretas aos gêneros textuais, produzindo novos gêneros, próprios da esfera digital (o meme, o gif), ou ainda transformando aqueles que circulam tanto na web como em outras esferas sociais (a notícia, a receita, por exemplo), numa linguagem híbrida. Dada a essa complexidade discursiva, é importante levantar como a Base Nacional Comum Curricular (doravante BNCC) preocupa-se com essa realidade e orienta o ensino da língua portuguesa, bem como discutir uma proposta de ensino que recorra à linguagem da web.

Embora compreendamos que a escola tradicional ainda é monocultural (CANDAU, 2000) e que sofre com a falta de recursos materiais e técnicos para o processo de ensino de aprendizagem dos estudantes, o que aumenta nossa angústia, almejamos contribuir e refletir sobre as possibilidades de um ensino pautado numa pedagogia dos multiletramentos, isto é, num processo que leve em consideração os novos e múltiplos letramentos que se fazem presentes na sociedade atual, de modo que a multiculturalidade e o aspecto multissemiótico atuem juntos em prol de um ensino mais crítico. Assim, assumimos, neste artigo, o objetivo de discutir o multiletramento, conforme prescrito na BNCC, de maneira a problematizar, mas, sobretudo, a estudar as possibilidades de análise e de ensino de textos multissemióticos (o meme) que circulam na web.

Para tanto, este artigo está dividido em mais quatro seções: uma relativa aos gêneros textuais na esfera digital e à BNCC; a seguinte referente à pedagogia dos multiletramentos e aos memes; outra quanto à análise que desenvolvemos; e, por fim, a última quanto as nossas considerações.

\section{Os gêneros textuais na esfera digital e a BNCC}

Ao dizer, ao escrever, ao ler, ao ouvir, estamos sempre em interação por meio de um gênero textual, que nas palavras de Bakhtin (2003) são enunciados relativamente estáveis integrados e transformados ao longo da história, da cultura de uma sociedade, e exercem diferentes funções em razão dos objetivos e situações em que são empregados e produzidos. Realizam-se, transformam-se na prática, enquanto atividade de linguagem, nas diversas interações humanas, próprias de uma dada comunidade, de uma dada esfera social, com determinado objetivo. Para Dolz e Schneuwly (2004, p. 74), "é através dos gêneros que as práticas de linguagem materializam-se", servindo "como um modelo comum, como uma representação integrativa que determina um horizonte de expectativas para os membros de uma 
Volume 14 - Número 2 - ago/dez de 2019

comunidade". Os autores ainda alertam que é a partir das "mediações comunicativas, que se cristalizam em gêneros, que as significações sociais são progressivamente reconstruídas" (SCHNEUWLY; DOLZ, 2004, p. 51). Em outros termos, existe um ciclo interminável de construção, reconstrução, desconstrução dos modos de dizer e dos sentidos possíveis de serem produzidos, compartilhados, ressignificados. Dessa maneira, a abordagem dos pesquisadores Dolz e Schneuwly (2004) e Bronckart (1999) apoia-se em Volochinov/Bakhtin (1999) e de seus postulados, e incisivamente defende que é fundamental:

(i) "não separar a ideologia da realidade material do signo (colocando-a no campo da "consciência" ou em qualquer outra esfera fugidia e indefinível); (ii) não dissociar o signo das formas concretas da comunicação social (entendendo-se que o signo faz parte de um sistema de comunicação social organizada e que não tem existência fora deste sistema, a não ser como objeto físico); e (iii) não dissociar a comunicação e suas formas de sua base material (infraestrutura)" (VOLOCHINOV/BAKHTIN, 1999, p. 47).

Bronckart (1999) defende que é graças ao agir comunicacional, marcado pelo emprego dos signos, que imprimimos às condutas humanas significados, isto é, interpretando-as, atribuindo a elas motivos, intenções e recursos ao se realizarem e é por meio do agir linguageiro que regulamos o agir praxiológico, o agir prático, destinado a criar as condições indispensáveis à existência da sociedade. Bakhtin/Volochinov (1999, p. 35) esclarecem que "não basta colocar face a face dois homo sapiens quaisquer para que os signos se constituam. É fundamental que esses dois indivíduos estejam socialmente organizados, que formem um grupo (uma unidade social): só assim um sistema de signos pode constituir-se". E esses signos não aparecem soltos, mas em textos singulares e concretos, exemplares de gêneros textuais.

Os estudos de Dolz e Schneuwly (2004), em colaboração com Sylvie Haller, sustentam que, para haver o domínio de um gênero, é preciso se ter a maestria da situação de comunicação que implica conhecimentos relativos: (i) à produção/recepção de um texto, isto é, ao contexto histórico e ao mais imediato de sua produção/recepção e de seu objetivo/função social; (ii) a sua arquitetura interna, com uma infraestrutura textual (plano geral do conteúdo temático, tipos de discursos e eventuais sequências); (iii) aos mecanismos de textualização (conexão e coesão nominal e verbal); (iv) e aos mecanismos enunciativos (modalização e vozes), o que requer um processo de desenvolvimento das capacidades de linguagem dos sujeitos. Nesse processo, diferentes capacidades são evocadas e apreendidas, como: a capacidade de ação (adequação quanto aos aspectos relativos ao contexto); a capacidade discursiva (recorrer a modelos discursivos) e a capacidade linguístico-discursiva (domínio das operações psicolinguísticas e das unidades linguísticas).

Sobre os gêneros textuais, Santaella (2013) afirma que nunca a teoria dialógica bakhtiniana se fez tão presente e relevante. A interação, a partir de um discurso híbrido, além de estar presente de modo massivo em diferentes circunstâncias, e em novos ambientes, ocorre também em uma velocidade ímpar, derrubando barreiras de tempo e de espaço, o que requer de nós, usuários e professores da linguagem, um olhar ainda mais atento às transformações e configurações dos modos de dizer e de fazer na sociedade. Dessa forma, é urgente compreender como os gêneros textuais se configuram nessa nova realidade linguageira multissemiótica, em que os valores e os sentidos são construídos e desconstruídos em tempo real e em tempo recorde e como a BNCC aborda tal temática.

A BNCC foi promulgada em dezembro de 2018 e, sendo um documento previsto pela Lei de Diretrizes e Bases da Educação Nacional (LDB, Lei n 9.394/1996), a "Base deve nortear os currículos dos sistemas e redes de ensino das Unidades Federativas, como também as propostas pedagógicas de todas as escolas públicas e privadas de Educação Infantil, Ensino Fundamental e Ensino Médio, em todo Brasil” (BNCC, 2018). Trata-se de um gênero textual 
prescritivo, próprio da esfera político-educacional, que visa à regulamentação e legitimação não apenas de um quadro curricular (conteúdos) comum a todo território nacional, mas também à instrumentalização e avaliação da atividade de trabalho do professor. Sabemos que o agir linguageiro impacta sobre o agir praxiológico, e a Base, enquanto prescrição, atua como um texto com o objetivo de orientar, direcionar, instruir sobre os modos de fazer uma dada atividade, bem como legitimar determinadas ações em detrimento de outras.

A prescrição deve ser compreendida como a "tarefa, o que deve ser feito e o que pode ser objetivamente descrita em termos de condições e de objetivo, de meios (materiais, técnicos...) utilizados pelos sujeitos" (AMIGUES, 2004, p.39), ou seja, consiste nas normas, nas regras de como deve ser executado determinado trabalho. Embora a prescrição seja norteadora, existe um hiato entre a tarefa normatizada no documento e a atividade realizada, pois o trabalhador, ao recorrer às normas de conduta de sua profissão, readéqua-as conforme as possibilidades de realização em situação de trabalho. Por isso, devemos nos ater aos aspectos que a Base determina quanto a uma pedagogia dos multiletramentos. Em uma leitura atenta, notamos que no texto da $\mathrm{BNCC}$ aparecem os termos multiletramentos e multissemióticos, mas sem haver em momento algum uma definição direta do que seriam e sem haver uma explicitação de como se poderia fazer a exploração das características relativas a eles. Em vários momentos do texto, ao se prescrever o que deve ser trabalhado, há apenas listas de conteúdos, como podemos ver na página 71, e não indicações de um trabalho que leve à compreensão dos efeitos de sentido gerados pelos recursos empregados. Será que a presença de uma lista de características de textos multissemióticos, como se vê abaixo (BNCC, 2018, p. 71), poderia garantir que o professor possa saber como trabalhá-los com os alunos?

\begin{tabular}{|c|c|}
\hline $\begin{array}{l}\text { Compreensão dos } \\
\text { efeitos de sentido } \\
\text { provocados pelos } \\
\text { usos de recursos }\end{array}$ & $\begin{array}{l}\text { - Identificar implícitos e os efeitos de sentido decorrentes de } \\
\text { determinados usos expressivos da linguagem, da pontuação e } \\
\text { de outras notações, da escolha de determinadas palavras ou } \\
\text { expressões e identificar efeitos de ironia ou humor. }\end{array}$ \\
\hline $\begin{array}{l}\text { linguísticos e } \\
\text { multissemióticos em } \\
\text { textos pertencentes a } \\
\text { gêneros diversos }\end{array}$ & $\begin{array}{l}\text { - Identificar e analisar efeitos de sentido decorrentes de escolhas } \\
\text { e formatação de imagens (enquadramento, ângulo/vetor, cor, } \\
\text { brilho, contraste), de sua sequenciação (disposição e transição, } \\
\text { movimentos de câmera, remix) e da performance - movimentos } \\
\text { do corpo, gestos, ocupação do espaço cênico e elementos sonoros } \\
\text { (entonação, trilha sonora, sampleamento etc.) que nela se relacionam. }\end{array}$ \\
\hline & $\begin{array}{l}\text { - Identificar e analisar efeitos de sentido decorrentes de escolhas } \\
\text { de volume, timbre, intensidade, pausas, ritmo, efeitos sonoros, } \\
\text { sincronização etc. em artefatos sonoros. }\end{array}$ \\
\hline
\end{tabular}

Se cada esfera de atividade produz os seus enunciados, também atribui significados para os seus signos, e os falantes que não pertencem a esta esfera podem ter dificuldades em compreender as escolhas que são feitas. Por exemplo, a questão do enquadramento, citada acima na BNCC (2018, p. 71), tão importante na produção de um roteiro para o trabalho com o audiovisual, será compreendida facilmente pelos professores? Será claro para os professores as diferenças entre um plano geral (PG), um plano americano (PA) ou um plano detalhe (PD) e os efeitos de sentido obtidos ao se escolher um ou outro (CANNITO; SARAIVA, 2010; FIELD, 2001; MARTIN, 2003), conforme detalham os autores que discutem o planejamento e produção de audiovisual?

Por um lado, compreendemos que a BNCC como toda prescrição será lacunar, pois não é possível detalhar todos os pontos possíveis, por outro, percebemos o nosso papel social enquanto pesquisadores da Linguística Aplicada e da Educação, de alertar sobre as falhas da BNCC, mas também de buscar, ao trabalharmos com signos, novos dispositivos que nos ajudem 
Volume 14 - Número 2 - ago/dez de 2019

a aprimorar o trabalho docente na escola, considerando as prescrições dos documentos oficiais. Nesse sentido, uma forma de ajudar os professores e elaboradores de materiais didáticos seria apresentando boas análises de gêneros multissemióticos que possam depois servir para fundamentar modelos didáticos.

\section{A pedagogia dos multiletramentos e os memes}

$\mathrm{Na}$ seção anterior, discutimos a importância da linguagem e sua implicação na construção de sentidos e na mudança de comportamentos, particularmente, compreendemos que a massificação dos diferentes modos de interação, a rapidez da circulação das informações e a proximidade entre culturas, entre diversos ambientes locais e globais, produzem uma rede discursiva multissemiótica em que o termo "multi" assinala seu valor. São múltiplos os valores, as intenções, os meios, os modos de dizer e fazer, os lugares de estar. Como enfatiza Santaella (2010), eis o momento em que o mundo, literalmente, está na palma da mão, ou ainda, diríamos nas digitais. Basta um toque, um dedo, um movimento e a tela se transforma, novos textos, novos temas, novos participantes, novos horizontes se abrem, e tudo isso ocorre apenas numa troca de grupos no Facebook. A mudança pode ser mais ou menos expressiva, todavia, é efetiva, presente e latente, quase como um organismo integrado a uma rede de alimentação de um todo complexo, em que as partes, alimentam e se alimentam do fluxo da vida, retomando Morin (2011). Nesse processo, outras capacidades são exigidas, como: acessar, selecionar, compreender, posicionar, articular, filtrar, compartilhar, responder, curtir, relacionar, ignorar.

Embora estejamos preocupados e buscando compreender essa linguagem híbrida própria de uma hipermídia, há 23 anos, em 1996, os estudiosos do Grupo Nova Londres (GNL) já defendiam uma pedagogia dos multiletramentos:

Esses pesquisadores já apontavam para a necessidade de que a escola tomasse a seu cargo [...] os novos letramentos emergentes em sociedade contemporânea [...] e de que levasse em conta e incluísse nos currículos a grande variedade de culturas presentes já nas salas de aula de um mundo globalizado e caracterizada pela intolerância na convivência com a diversidade cultural. [...] Diferentemente do conceito de letramentos (múltiplos), o conceito de multiletramentos - é bom enfatizar - aponta para dois tipos específicos e importantes de multiplicidade presentes em nossas sociedades, principalmente urbanas, na contemporaneidade: a multiplicidade cultural das populações e a multiplicidade semiótica de constituição dos textos por meio dos quais ela se informa e se comunica (ROJO, 2012, p. 12-13).

Trata-se, portanto, de uma pedagogia preocupada em tornar o estudante uma pessoa crítica, consciente de seu papel e do fenômeno linguístico enquanto práxis poderosa na construção e desconstrução de sentidos, de valores, de estereótipos, de perspectivas. Em outras palavras, defendemos que o ensino esteja atento às práticas sociais de leitura e escrita de forma ética, crítica e democrática. Nas palavras de Rojo (2012), é importante uma pedagogia multiletrada (ROJO, 2012) que leve em consideração as novas ferramentas (de áudio, de vídeo, de tratamento de imagens, de edição, de diagramação), os novos contextos de produção e recepção de textos, as novas formas de organização e de interação próprios da web, como o meme. Os memes podem ser um ótimo recurso didático-pedagógico no processo de ensino e de aprendizagem da língua portuguesa, já que são gêneros textuais típicos da esfera digital, que satirizam, ironizam as condutas, os pensamentos de uma dada comunidade e, por isso, viralizam e são muito consumidos. Além de divertidos e efêmeros, utilizam diferentes modos de linguagem, como textos escritos, imagens, som, vídeo, e, embora passem de pessoa para pessoa, 
os memes tornam-se um fenômeno social ao viralizarem na web, podendo influenciar modos de pensar, de agir e de reagir a determinados acontecimentos sociais (SHIFMAN, 2014).

A palavra "meme" originou de estudos da sociobiologia em 1976, por meio do bestseller "The Selfish Gene" de Richard Dawkins, que cunhou o termo para dar conta dos processos de replicação e evolução cultural. O biólogo adaptou a raiz grega "mimeme" $(\mu i ́ \mu \eta \mu \alpha)$ e criou o "meme", sinônimo de mimese - imitação. Sobre isso, os estudos do antropólogo e educador Christoph Wulf (2013, p.14) contribuem significativamente, uma vez que defendem a imitação como uma forma de ação (rito) que auxilia na configuração social a partir do processo da mimesis que passa pela "assimilação de um oposto", seja ele uma pessoa, um outro mundo ou outras ideias e ideais. É somente pelos processos miméticos que o homem consegue transformar o mundo externo e a si mesmo e, nesse processo, quanto maior o aprendizado mimético, mais o ser humano se torna sensível ao mundo. Os memes se orientam nesse processo em que se propagam pela sociedade (e redes sociais) e sustentam, fomentam, criticam, sublinham, negam e legitimam determinados ritos ou padrões socioculturais.

Com o avanço da World Wide Web, surgiram espaços abertos e colaborativos que permitem certa liberdade e criatividade dos usuários de todos os lugares do mundo, como, 4chan, Reddit, etc. (CHEN, 2012). São nesses web-fóruns que os memes encontram terreno fértil para sua produção, recepção e seleção. Antes de viralizarem nas redes sociais, são expostos nesses fóruns em que a censura ou o controle de autoria são muito relativizados. São populares, mas complexos, já que envolvem uma diversidade de temas (uns mais ou menos importantes), de linguagens (verbais e não-verbais), mas sobretudo de figuras de linguagens, como a ironia, que intensificam as tensões valorativas dos textos.

Os memes não são outra coisa que um gênero textual e, com a fugacidade do tempo, com a atenuação das fronteiras entre o global e o local, o privado e o público, com a velocidade e a multiplicação de uma nova forma de interação nas redes sociais, o meme torna-se um rico objeto de análise e de crítica quanto aos temas, aos comportamentos legitimados ou não na sociedade. Vale ressaltar que o gênero, próprio da esfera digital, recorre a diferentes temas, bem como a estruturas e linguagens que os diferenciam entre si e, ao mesmo tempo, marca a complexa rede discursiva da internet. Existe uma variação quanto à classificação por formato (memes imagéticos, textuais, sonoros e audiovisuais) e por categorias (image-macros; exploitables; look-alikes; selfies; snowclones; rager comics; memes forçados; efeito streisand; etc.). Conforme as descrições disponíveis no site Know Your Meme ${ }^{3}$, rage comics é uma espécie de História em Quadrinhos, diferente do snowclones que são um tipo de gabaritos frasais, ou seja, existe uma frase curta em que certas palavras podem ser substituídas por outras para produzir novas variações com significados alterados, por exemplo, "quando digo X, o que realmente quero dizer é Y".

Figura 1: Meme rager comics.

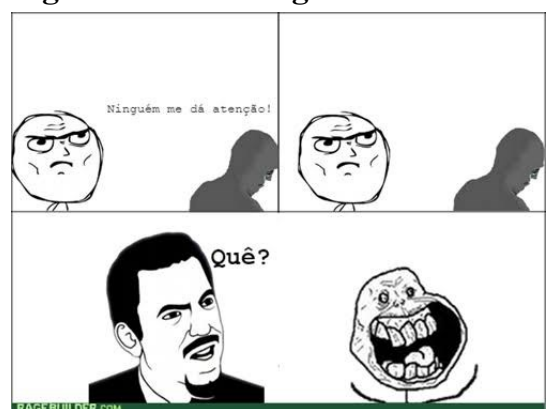

Fonte: https://knowyourmeme.com/memes
Figura 2 : Meme Snowclones.

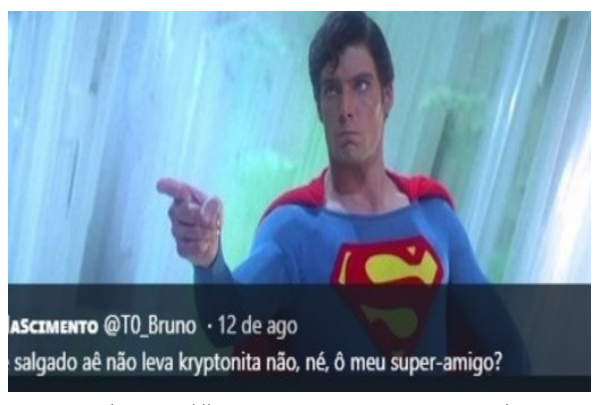

Fonte: https://knowyourmeme.com/memes

\footnotetext{
${ }^{3}$ Para maiores informações: https://knowyourmeme.com/memes.
} 
Para Recuero (2007), os memes também podem ser avaliados em relação a sua replicação, isto é, a suas características quanto: à longevidade (capacidade de permanecer sendo utilizado ao longo do tempo); à fecundidade (capacidade de gerar cópias e se reproduzir); e à fidelidade (capacidade de gerar novas cópias mais semelhantes, fieis ao original).

Devido a essa alta diversidade, selecionamos memes imagéticos de categoria imagemacro ${ }^{4}$, conforme a figura 4 , para análise e discussão quanto às características do gênero textual. A proposta consiste em levantar os aspectos mais comuns do gênero de modo a contribuir com futuras propostas de ensino e de aprendizagem desse objeto discursivo. Para tanto, buscamos primeiro compreender o fenômeno relativo à imagem, para isso recorremos à Rojo e Moura (2019) que discutem a imagem estática a partir de três paradigmas distintos: o pré-fotográfico, o fotográfico e pós-fotográfico. Para os autores, a imagem passa por três processos distintos: no pré-fotográfico, é artesanal; no fotográfico, dá-se por meio da máquina; e, no pós-fotográfico, ocorre através da computação. Evidentemente, que sendo o meme um gênero tipicamente da esfera digital, o tratamento de suas imagens, na maioria das vezes, é realizado por meio de recursos tecnológicos, o que lhe confere a característica de pósfotográfico. Rojo e Moura (2019), fundamentados nos estudos de Santaella e Noth (2014), esclarecem que o pós-fotográfico não se configura como uma obra do artista, seja um artista plástico, seja um fotógrafo, na verdade existe uma "matriz numérica gerada por programas de computador que se valem de processos lógico-matemáticos para criar a imagem em pixels" (op. cit., 2019, p. 75). Os recursos são inúmeros para a edição de imagens que possuem acesso e uso fácil, explicativo. Dessa forma, toda e qualquer pessoa pode tratar a imagem, além de associála a diferentes textos verbais que permitem novas possibilidades de leitura e de interpretação. Vejamos o exemplo do meme criado com o rosto do ex-presidente Barack Obama que viralizou na internet. Na ocasião, enquanto presidente Obama realizava uma visita oficial à Inglaterra, o meme de característica image-macro, foi muito utilizado para legitimar diferentes comportamentos por meio da expressão da foto e da frase "not bad" que se pode traduzir como "nada mal".

Figura 3: Meme image-macro.

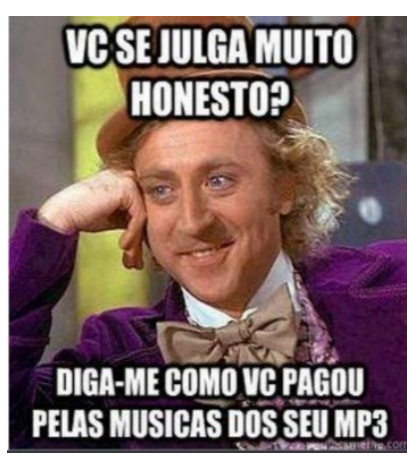

Fonte: http://www.ileel.ufu.br/.
Figura 4: Fotografia de Barack/Michele Obama.

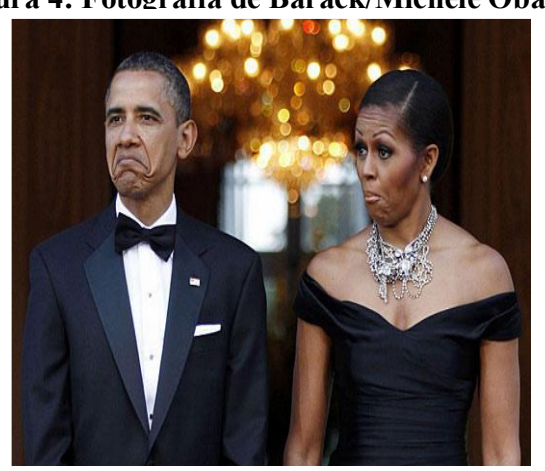

Fonte: https://oglobo.globo.com.
Figura 5: Meme image-macro.

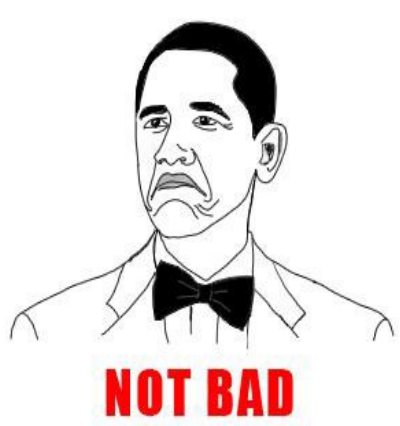

Fonte: https://ballmemes.com.

\section{Análise e estudo do gênero: o caso dos memes}

Faremos a análise de diferentes memes do tipo image-macro que atua com imagens e textos e recorre a diferentes temas: os de cunho político, os de cunho social (meio ambiente, homofobia, feminismo etc.), os de cunho psicológico (dieta, preguiça etc.), todavia nos focaremos em temas de cunho político. Isso é importante porque o domínio da ação de

\footnotetext{
${ }^{4}$ As famílias de memes não costumam ser excludentes, portanto pode haver mistura entre elas, uma look-alike com image-macro, por exemplo. Conforme Chagas et. all. (2017).
} 
linguagem passa pela maestria dos conteúdos temáticos, pois os "conhecimentos mobilizados organizam-se em mundos 'outros', ou em mundos discursivos" que representam os valores dentro de uma determinada esfera discursiva (BRONCKART, 1999, p. 98).

A análise dar-se-á particularmente em relação: (i) à produção/recepção do texto, isto é, ao contexto sócio-histórico e ao mais imediato de sua produção/recepção, bem como seu objetivo/função social; (ii) a sua arquitetura interna (plano geral do conteúdo temático, tipos de discursos e eventuais sequências); (iii) aos mecanismos de textualização (conexão e coesão nominal e verbal); (iv) e aos mecanismos enunciativos (modalização e vozes). A proposta é trabalhar as características verbais com as não-verbais (as imagens estáticas), buscando sempre apreender os efeitos de sentidos construídos.

\section{Figura 6: Meme Lindsay Loran}

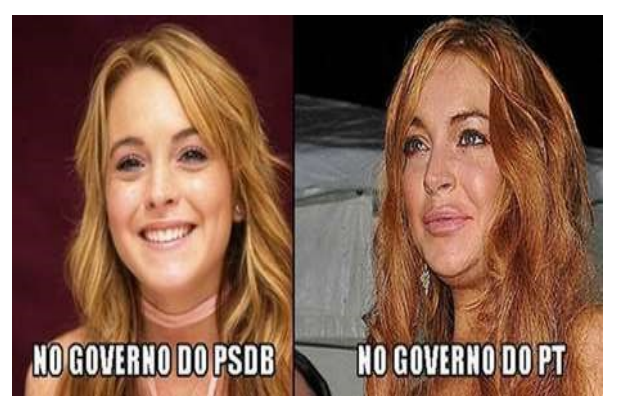

Fonte: https://www.terra.com.br/noticias/eleicoes/aecioneves/internautas-brincam-com-apoio-de-lindsay-a-aeciovejamemes,9b04554907339410VgnVCM3000009af154d0 RCRD.html

\section{Figura 7: Meme Aécio presidente}

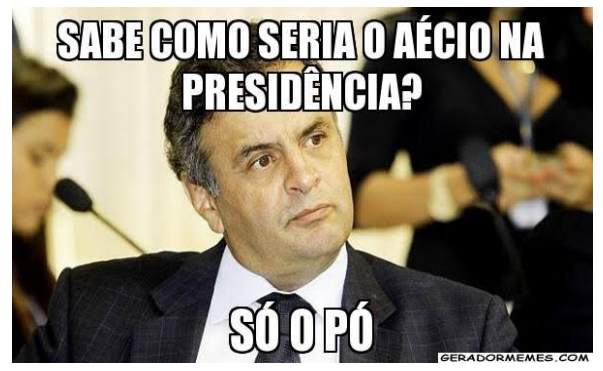

Fonte:https://www.imagemwhats.com.br/meme s-aecio-ladrao/

Os memes acima foram produzidos ao longo da campanha eleitoral de 2014, que segundo Chagas et.all., (2017, p.174) ficou conhecida como as "eleições dos memes". Segundo o autor, tudo era motivo para piada, vários jornais como a Folha de São Paulo e o Estado de São Paulo publicaram piadas sobre os diferentes candidatos, particularmente, sobre a rivalidade que se estabeleceu entre dois candidatos: Dilma Roussef, do Partido dos Trabalhadores - PT, e Aécio Neves, do Partido da Social Democracia Brasileira - PSDB. A influência das mídias sociais, em especial, Twitter e Facebook, levou os candidatos a desenvolverem estratégias de marketing pró seus interesses e contra os dos demais. Conteúdos foram produzidos e veiculados por meio de robôs e contas falsas, o que ampliou o alcance das mensagens, reproduzindo e replicando-as significativamente (CHAGAS et. all., 2017).

Embora fossem três candidatos a presidente por coligações e oito candidatos representando apenas um partido, ou seja, onze candidatos ${ }^{5}$ à presidência do país, o que se instalou foi uma clara divisão entre duas possibilidades, eleger um novo partido, o Partido da Social Democracia Brasileira - PSDB, ou reeleger o Partido dos Trabalhadores - PT.

Nesse processo, internautas admiradores e defensores de seus candidatos, além de robôs e contas falsas ${ }^{6}$ produziram e compartilharam muitos memes tematizando os contrastes entre os governos, ou problemas relacionados diretamente aos candidatos. Desta forma, é difícil identificar os produtores do texto, todavia fica evidente que os produtores buscam desmerecer

\footnotetext{
${ }^{5}$ Ver http://www.tse.jus.br/eleicoes/eleicoes-anteriores/eleicoes-2014/candidaturas/divulgacao-de-candidaturasdivulgacand-2014. Última visita em: 01/11/2019.

${ }^{6}$ Pablo Ortellado, professor da Universidade de São Paulo, esclarece que os robôs e as contas falsas são estratégias distintas de manipulação na internet. Enquanto os robôs são máquinas dando respostas prontas, multiplicando uma falsa interação, previamente programada; as contas falsas são de internautas que, com diferentes interesses, gerenciam e multiplicam informações na rede. Ver: https://g1.globo.com/economia/tecnologia/noticia/o-que-eum-robo-na-web-e-como-ele-pode-influenciar-o-debate-nas-redes-especialistas-explicam.ghtml. Última visita em: 01/11/2019.
} 
Volume 14 - Número 2 - ago/dez de 2019

o adversário em favor do seu candidato, particularmente visam a reforçar o aspecto negativo, o desprestígio do outro. Além disso, quanto à recepção dos memes, o que fica evidente é que as redes sociais foram o grande suporte de veiculação e difusão, o que torna o alcance um elemento extremamente expressivo. A rede discursiva que se instalou foi de uma efetiva arena de luta, retomando Volochinov/Bakhtin (1999), em que o embate não é propriamente um interdiscurso construtivo, mas sobretudo destrutivo: ao desqualificar um, sublinha-se outro.

No primeiro meme, figura 6 , existe uma variação quanto ao tipo, o image-macro mistura com a proposta look-alike que consiste em recorrer a quadros com sósias de personalidades, embora não seja uma sósia, mas sim a foto da própria atriz Lindsay Lohan a ideia do contraste é mantido para reforçar a contradição entre os partidos. O meme emergiu a partir do fato de a Lindsay Lohan ${ }^{7}$ ter postado no Twitter sua preferência por Aécio Neves, todavia o conhecimento de a atriz já ter vivenciado vários escândalos devido ao uso de drogas e bebidas não favorece efetivamente o candidato. Essa situação se agrava quando relacionada com a notícia de que um helicóptero da família Perrella ${ }^{8}$ (aliados do candidato) abasteceu em uma de suas propriedades com 450 kilos de pasta base de cocaína. Observa-se que os memes dialogam com fatos, textos (notícias), condições que estão além do texto, são aspectos de intertextualidade, de conhecimentos que, se não compartilhados, podem prejudicar a compreensão e os efeitos de sentido pretendidos.

No primeiro meme, figura 6 , a estrutura se organiza com duas fotos, uma da atriz com aspecto saudável, singela, sorridente, consciente e outra com aparência de doente ou de embriagada, com cabelos alvoraçados. As imagens são elementos que modalizam o que fora dito. Assim, os textos, inseridos no final da página com o dizeres "no governo do PSDB" e "no governo do PT", associam o aspecto negativo (doente) da atriz ao PT e o aspecto saudável ao PSDB. Todavia outras relações podem ser construídas e uma leitura rápida, sem associação aos demais aspectos sócio-históricos, pode reduzir as possibilidades de sentido. O tipo de discurso é interativo em que implica não apenas os partidos, mas o navegador da net (o destinatário), pois é como se estabelecesse uma comparação entre condições e as apresentasse ao interlocutor. Existe um diálogo, não apenas com o destinatário, mas sobretudo com outros textos, notícias, fatos. São vozes que implicam novas possibilidades de significados.

O segundo meme, figura 7, organiza-se a partir da imagem do candidato, mais frases na parte superior e na parte inferior do meme. Trata-se de uma foto do candidato com um olhar interrogativo, que dialoga com a pergunta "Sabe como seria o Aécio na presidência?" e com a resposta "só o pó". O tema refere-se diretamente à possível eleição do candidato e das possíveis consequências, se levadas em consideração as notícias divulgadas sobre as pastas de base de cocaína. A intertextualidade é explícita, a interlocução ainda mais efetiva, o que traz uma implicação persuasiva ainda maior. O discurso interativo associado à modalização "só" que marca uma única possibilidade, excluindo quaisquer outras, e mais a imagem do candidato que inclina a cabeça para refletir, como se ele mesmo buscasse compreender algo, fazem do meme um texto de alto poder persuasivo.

Ainda sobre as imagens é interessante constatar que as origens das fotos não são retomadas, bem como as fontes das notícias; na verdade, trata-se de uma atividade de linguagem em que a informalidade é bastante significativa, com gírias "o pó", abreviações "vc" próprias de textos mais informais da esfera digital. Ademais, o uso da imagem e do texto se faz sem critérios de controle, o que contribui para a produção e replicação de memes sem compromisso com a verdade ou com o esclarecimento. Estar atento a isso é fundamental para uma leitura mais crítica e emancipatória dos efeitos de sentido e objetivos pretendidos por um meme.

\footnotetext{
${ }^{7}$ Conforme disponível em: https://exame.abril.com.br/tecnologia/atriz-lindsay-lohan-apoia-candidatura-de-aecioneves-no-twitter-e-vira-motivo-de-piada/ Última visita em: 01/11/2019.

${ }^{8}$ Para saber mais: https://veja.abril.com.br/brasil/o-helicoptero-de-perrella-e-as-acoes-controladas/
} 
Aqueles que produzem e compartilham um meme têm uma grande responsabilidade, pois o meme multiplica-se e atua diretamente na produção de uma rede discursiva em que ideias e comportamentos são legitimados ou não, esse processo requer uma leitura crítica, consciente e atenta. Santaella (2013) alerta que nunca foi tão importante compreender a teoria bakhtiniana sobre o dialogismo. É interessante observar como o tema sobre política é recorrente e pode acontecer de diferentes maneiras, como nas eleições de 2018 em que a atitude de uma internauta tatuadora e pesquisadora torna-se uma voz dissonante dos resultados eleitorais e, ao mesmo tempo, uma voz de esperança e de luta entre um dado grupo. Não se pode esquecer como o meme torna-se um instrumento de luta, de persuasão entre diferentes grupos, retomando a arena de lutas valorativas de Volochinov/ Bakhtin (1999).

Figura 8: Mimimi

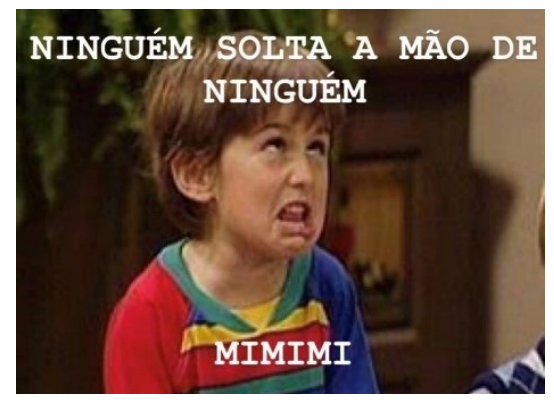

Fonte:https://www.museudememes.c om.br/sermons/ninguem-solta-a-maode-ninguem/

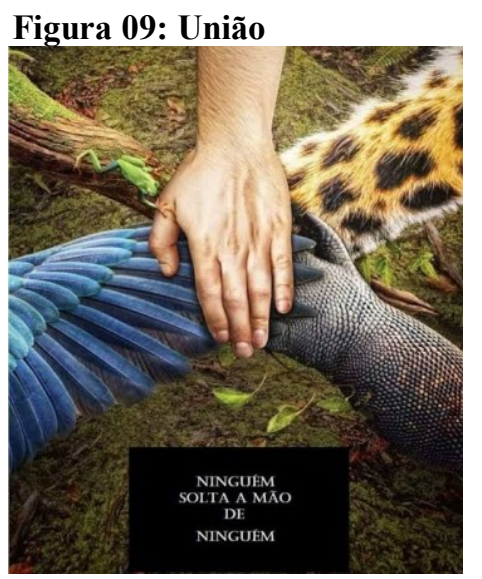

Fonte:https://www.museudememes com.br/sermons/ninguem-solta-amao-de-ninguem/
Figura 10: Lula e Temer ${ }^{9}$

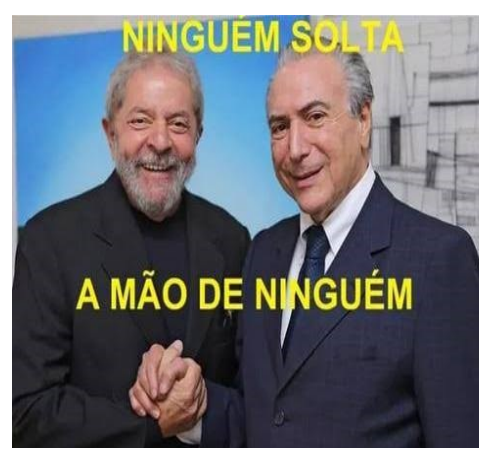

Fonte:https://lulacerda.ig.com. $\mathrm{br} / \mathrm{memes}$-da-prisao-demichel-temer-de-tedio-obrasil-nao-morre/

Segundo o site Museu do Meme, logo após o resultado da eleição do presidente Jair Bolsonaro no dia 29/10/2018, uma imagem com mãos dadas segurando uma rosa com a frase "ninguém solta a mão de ninguém" foi postada nas redes sociais e repercutiu como uma mensagem de "esperança" para um dado grupo. A imagem foi criada pela tatuadora e pesquisadora Thereza Nardelli, de 30 anos, que nasceu em Belo Horizonte e é formada em Ciências Sociais, com mestrado na área de Comunicação Social. A frase "ninguém solta a mão de ninguém" viralizou, tornou-se um catchphrase, isto é, uma frase de efeito que foi replicada em diferentes tipos de memes. A origem da mesma é polêmica pois, segundo a autora, é de sua mãe que buscou confortá-la, mas segundo o jornal GGN, em novembro de 2018, a frase teria sido o "grito de pavor" de estudantes do curso de ciências sociais da USP durante a invasão de soldados na ditadura militar.

A figura 8 traz a imagem da personagem Aaron Bailey (ator Miko Hughes) da série dos anos 90, "Três é demais". A personagem caçoava os demais com caretas de deboche. Enfim, a imagem é utilizada em diferentes memes e nesse caso faz referência à frase "ninguém solta a mão de ninguém" e o quanto isso é uma "frescura", "um mimimi". O meme foi utilizado para diminuir a importância dada ao tema que consiste numa produção de ação popular, em prol daqueles que, de alguma forma, pudessem se sentir perseguidos, oprimidos pelo novo governo. O lema, um tipo de discurso interativo, já que o pronome "ninguém" promove a inclusão de todos numa ação contrária da frase "soltar a mão", tornou-se símbolo de luta, principalmente

\footnotetext{
${ }^{9}$ Para saber mais: https://www.em.com.br/app/noticia/politica/2016/03/30/interna politica,748559/do-namoroao-divorcio.shtml
} 
para minorias como os LGBT's, negros, mulheres, indígenas e animais (o que a figura 9 procura reforçar). A figura 9, no centro, dialoga com a proposta de liberação da caça esportiva no país, uma vez que a imagem destaca várias patas, asas de diferentes animais, inclusive a do próprio homem que se reúne a eles em defesa da vida da biodiversidade. Dessa forma, existe uma intertextualidade quanto a outras propostas e medidas governamentais que estavam em trâmite na ocasião. O terceiro e último meme à direita refere-se à relação entre Michel Temer e Luis Inácio Lula da Silva. A foto, retirada em 2015, foi utilizada novamente para fazer uma crítica às relações políticas. Existe uma voz que faz crítica a quem nos aliamos, pois a foto retoma todo o conteúdo sócio-histórico de coligações e relações entre o Partido do Movimento Democrático Brasileiro (PMDB) e o Partido dos Trabalhadores.

Vale ressaltar que o PMDB é um partido de orientação de direita, que apoiou Fernando Henrique Cardoso (PSDB) e que nas eleições de 2002 trabalhou contra Luis Inácio Lula da Silva, apoiando José Serra (PSDB) para presidente e Rita Camata (PMDB), para vice, porém perderam as eleições. No segundo governo Lula, o PMDB formalizou seu apoio, integrando o chamado Ministério da Coalizão, a partir de então, nas eleições seguintes, Michel Temer foi o vice-presidente de Dilma Roussef. Após duas vitórias consecutivas, no segundo mandato de Dilma Roussef, Temer apoia e lidera o movimento pró-impeachment da presidente que saiu do cargo em agosto de 2016. Temer presidiu o Brasil até final de 2018.

Novamente, o que se constata é a complexidade temática e das relações que estabelece com outros dados, outros textos, outros fatos. Aqui fica evidenciada a rede discursiva, em que os produtores de grupos distintos, que assumem perfis ideológico-políticos também distintos, cumprem o papel social de críticos quanto às relações políticas, aos embates e aos apertos de mãos existentes dada as circunstâncias e interesses na vida política.

Em síntese, compreendemos que a esfera discursiva digital contribui para mudanças nas relações e atividades de linguagem, todavia, devido a uma grande efervescência na produção/recepção dos gêneros na internet, é importante destacar a urgência em discutir como as práticas linguageiras ocorrem, com quais interesses e prestando a que tipo de serviço. $\mathrm{O}$ termo "fanduns", por exemplo, consiste no nome dado ao conjunto de fãs, com identidades, valores, objetivos particulares, que formam um grupo, uma "subcultura" (CHAGAS et. all., 2017 em nota) que visa a alimentar e a ampliar seu poder de ação na internet. Em outros termos, as produções e compartilhamentos não ocorrem apenas com internautas casuais, aqueles que todos os dias navegam na internet, mas sobretudo de robôs, de contas falsas, de internautas especialistas, como jornalistas, blogueiros, etc. (ALDÉ, 2011), o que traz grandes implicações sobre os possíveis interesses de quem produz e de quem compartilha.

Essa característica exige conhecimentos além do texto, particularmente do contexto sócio-histórico que sustenta, justifica e nutri não só a emergência de um dado meme, mas sua longevidade, pois ele é produto de um evento social, de um fato, de uma discussão, de uma ideia, de uma rede discursiva efetiva, nas palavras de Volochinov/ Bakhtin (1999), de uma organização social. Os memes analisados, com uma a duas imagens, destacam em frases curtas em tom de informalidade e de sátira a temas de suma importância para a sociedade. Isso é importante porque a brevidade, a informalidade e principalmente o humor contribuem para a constituição de identidades coletivas, de reconhecimento de experiências, de ideias, de comportamentos, isto é, de perspectivas político-ideológicas de modo mais sutil, menos denso (SHIFMAN, 2014), levando à falsa impressão de que o tema está dominado, compreendido pela maioria das pessoas. Todavia não podemos esquecer que a política trabalha com relações de poder em que uma minoria atua sobre a maioria ou em prol dela e, para compreendê-la, é preciso estar atento aos detalhes, com leituras e releituras dos acontecimentos. Por isso, o trabalho com gêneros da esfera digital é tão significativo, para que os alunos possam reconhecer esses modos de manobra das diferentes ideologias, tornando-se sujeitos conscientes, críticos, emancipados para uma participação cidadã mais ativa, aptos a fazer suas escolhas. 
Volume 14 - Número 2 - ago/dez de 2019

\section{Considerações finais}

A partir da prescrição oficial da BNCC, objetivamos estudar uma das possibilidades de análise e de ensino de textos multissemióticos (os memes) que circulam na web, um desafio para leigos do mundo digital, tendo em vista as nuances dos gêneros textuais que circulam nessa esfera assumem. O meme, embora seja de linguagem simples, popular, com imagens em planos detalhados, na maioria dos casos, apresenta temas complexos e significativos para a sociedade em geral. Engana-se aquele que compartilha um meme como um simples ato de "brincadeira". $\mathrm{Na}$ verdade, o meme é uma atividade de linguagem persuasiva que legitima e multiplica um comportamento social, uma ideia, uma perspectiva ideológica. Sua força de abrangência nas redes sociais o torna um grande aliado ou inimigo, a depender do grupo sócio-cultural no qual nos inserimos.

Nesse sentido, o processo de ensino e de aprendizagem da língua precisa estar atento a esses detalhes, pois, conforme os conhecimentos que se tem, a interpretação varia, os efeitos de sentido se ampliam ou restringem-se. É preciso compreender que a imagem configura um sentido, o verbal, outro; mas como texto na íntegra, um sentido será aprendido pelo destinatário que pode, inclusive, oscilar em relação ao de quem almejou depreender. Enfim, são várias as possibilidades, e pensando nisso, o professor pode buscar analisar a imagem e o verbal, além de seus valores e de suas procedências; identificar os sentidos possíveis construídos a partir da junção da imagem com o verbal em dado contexto sócio-histórico; propor que se coloquem outras frases junto às imagens; ou ainda, outras imagens junto às frases; bem como explorar a cadeia de sentidos e os efeitos sociais que podem ser criados a partir dos interesses de cada grupo em um dado contexto sócio-histórico.

O estudo dos memes, neste artigo, é mais um recurso para os que buscam uma maior compreensão dos gêneros textuais próprios da esfera digital, particularmente dos memes, todavia estamos convencidos de que há muito a estudar, a discutir, a dialogar. Sendo assim, defendemos que contribuir com a rede discursiva que privilegie o ensino dos memes é mais uma forma de colaborar com a pedagogia do multiletramento, de modo que professores, pesquisadores, estudantes tenham a oportunidade de interagir com e sobre eles.

\section{Referências}

AMIGUES, R. Trabalho do professor e trabalho de ensino. In: A. R. Machado (Org.) O ensino como trabalho. Uma abordagem discursiva. Londrina. Eduel: 2004, (p. 35-53) 325p.

ALDÉ, A. O internauta casual: notas sobre a circulação da opinião pública na internet. Revista USP, São Paulo, n. 90, 2011.

BAKHTIN, M, M. Estética da criação verbal. São Paulo: Martins Fontes, 2003.

BRASIL. Base Nacional Comum Curricular: Educação Infantil e Ensino Fundamental. Brasília: MEC/Secretaria de Educação Básica, 2018.

BRONCKART, J-P. Atividades de linguagem, textos e discursos: por um interacionismo sócio-discursivo. Tradução de Anna Raquel Machado e Péricles Cunha. São Paulo: Educ. 1999. CANDAU, V. M. Reinventar a Escola. Petrópolis: Vozes, 2000.

CANNITO, Newton; SARAIVA, Leandro. Manual de roteiro: ou Manuel, o primo pobre dos manuais de cinema e tv. São Paulo, SP: Conrad Editora. 2010.

CHAGAS, V.; TOTH, J.P. 2016. Monitorando memes em mídias sociais. In: T. SILVA; M. STABILE (org.), Monitoramento e pesquisa em mídias sociais: metodologias, aplicações e inovação. São Paulo, Uva Limão, p. 211-234.

CHAGAS, V.; FREIRE, F.; RIOS, D.; MAGALHÃES, D. A política dos memes e os memes da política: proposta metodológica de análise de conteúdo de meme dos debates eleitorais de 
Volume 14 - Número 2 - ago/dez de 2019

2014. Intexto, Porto Alegre, UFRGS, n. 38, p. 173-196, jan./abr. 2017. DOI: http://dx.doi.org/10.19132/1807-8583201738.173-196. Última visita em 02/11/2019.

CHEN, Carl. The creation and meaning of internet memes in 4chan: Popular internet culture in the age of online digital reproduction. New Haven, CT: Institutions Habitus Spring, 2012.

DOLZ, J.; SCHNEUWLY, B. Gêneros orais e escritos na escola. Trad. Roxane Rojo e Glaís Cordeiro. Campinas, SP: Mercado de Letras, 2004.

FIELD, Sid. Manual do roteiro: os fundamentos do texto cinematográfico. Rio de Janeiro: Objetiva, 2001.

KLEIMAN, A.B.; MORAES, S.E. Leitura e interdisciplinaridade: tecendo redes nos projetos da escola. Campinas: Mercado de Letras, 1999.

LEMKE, Jay L. Letramento metamidiático: transformando significados e mídias. Trabalhos em Linguística Aplicada. Campinas, v. 49, n. 2, p. 455-479, dez. De 2010. Disponível em http://www.scielo.br/scielo.php?script=sci_arttext\&pid=S0103-

18132010000200009\&lng=en\&nrm=iso Acesso em: 15 de julho de 2019.

LIMA, M. B.; DE GRANDE, P. B. Diferentes formas de ser mulher na hipermídia. In: Escol@ conectada: os multiletramentos e as TICs. Organização Roxane Rojo - $1^{\mathrm{a}}$ e. São Paulo, Parábola Editorial, 2013.

MARTIN, M. A linguagem cinematográfica. Tradução de Paulo Neves. São Paulo, SP: Brasiliense, 2003.

MORIN, E. Os sete saberes necessários à educação do futuro. São Paulo: Cortez: Brasília, UNESCO, 2011.

RECUERO, R. C. Memes em weblogs: proposta de uma taxonomia. Conexões nas Redes Midiáticas. Revista FAMECOS, Porto Alegre, n. 32, p. 23-31, abr. 2007. Disponível em: http://revistaseletronicas.pucrs.br/ojs/index.php/revistafamecos/article/view/3411/2675.

Acesso em: 30/10/2019

ROJO, R. Pedagogia dos Multiletramentos: diversidade cultural e de linguagens na escola. In: Multiletramentos na escola. Roxane Rojo e Eduardo Moura [orgs] - São Paulo: Parábola Editorial, 2012.

ROJO, R.; MOURA, E. Letramentos, Mídias, Linguagens. São Paulo, Parábola Editorial, 2019.

SANTAELLA, L. Comunicação oblíqua: repercussões na cultura e na educação. São Paulo, Papulus, 2013.

SANTAELlA, L. Desafios da ubiquidade para a educação. Revista Ensino Superior Unicamp. Campinas/SP., Número Especial, p. 19-28, 2010. Disponível em: https://www.revistaensinosuperior.gr.unicamp.br/edicoes/edicoes/ed09 abril2013/NMES_1.p df. Última visita em: 28/10/2019.

SHIFMAN, L. Memes in a Digital Culture. Cambridge: The MIT Press, 2014.

VOLOCHINOV, V. N.; BAKHTIN, M. (1999) Marxismo e filosofia da linguagem: problemas fundamentais do método sociológico na ciência da linguagem. Prefácio de Roman Jakobson; apresentação de Marina Yaguello; tradução de Michel Lahud e Yara Frateschi Vieira; colaboração de Lúcia Teixeira Wisnik e Carlos Henrique D. Chagas Cruz - 9a . Ed. - São Paulo: Hucitec, 1999.

WULF, C. Homo Pictor: imaginação, ritual e aprendizado mimético no mundo globalizado. São Paulo: Hedra, 2013, p. 216. 